\title{
Choledochal Cyst
}

National Cancer Institute

\section{Source}

National Cancer Institute. Choledochal Cyst. NCI Thesaurus. Code C2943.

Cystic dilatation of the hepatic duct or bile duct. 